\title{
Correction to: Rilonacept (Interleukin-1 Inhibition) for the Treatment of Pericarditis
}

\author{
Tom Kai Ming Wang ${ }^{1} \cdot$ Allan L. Klein ${ }^{1}$
}

Published online: 26 January 2022

(c) Springer Science+Business Media, LLC, part of Springer Nature 2022

\section{Correction to: Current Cardiology Reports (2022) \\ https://doi.org/10.1007/s11886-021-01621-0}

Table 1 in the original publication of this article contains two incorrect data.

The original article has been corrected.

Publisher's Note Springer Nature remains neutral with regard to jurisdictional claims in published maps and institutional affiliations.

The original article can be found online at https://doi.org/10.1007/ s11886-021-01621-0.

Allan L. Klein

kleina@ccf.org; wangt2@ccf.org

1 Center for the Diagnosis and Treatment of Pericardial

Diseases, Section of Cardiovascular Imaging, Heart,

Vascular and Thoracic Institute, Cleveland Clinic, Cleveland,

$\mathrm{OH}, \mathrm{USA}$ 